\title{
19. VOLCANOGENIC SEDIMENTS FROM HESS RISE AND THE MID-PACIFIC MOUNTAINS, DEEP SEA DRILLING PROJECT LEG 62
}

\author{
T. L. Vallier, U.S. Geological Survey, 345 Middlefield Road, Menlo Park, California \\ and \\ W. S. Jefferson, Department of Geosciences, University of Arizona, Tucson, Arizona
}

\begin{abstract}
Volcanogenic sediments are most abundant in the Cretaceous sequences of the holes drilled during Deep Sea Drilling Project Leg 62. Volcanic contributions to the Cenozoic sequences are rare. Volumetrically significant volcanogenic sediments are in the Barremian-Aptian, upper Albian-lower Cenomanian, and Campanian-Maastrichtian intervals. The major volcanic events responsible for accumulation of Cretaceous volcanogenic sediments at Leg 62 sites probably were also responsible for volcanogenic components at other sites in the western Pacific, particularly on the OntongJava and Manihiki Plateaus and Horizon Guyot, and along the Line Island chain. Volcanism apparently was related both to the early formation of these rises and plateaus at mid-ocean ridges and to later intraplate tectonism.
\end{abstract}

\section{INTRODUCTION}

Most aseismic oceanic plateaus and rises of the western Pacific Ocean are characterized by relatively thick deposits of Cretaceous carbonate sediments. There are two major reasons for the thickness: (1) the plateaus and rises have been above the regional calcitecompensation depth through a large part of their histories, and (2) they passed under a zone of high biological productivity near the equator during northward plate movement (Lancelot, 1978). Siliceous fossils, particularly radiolarians, also were deposited rapidly, but contributions by siliceous organisms generally are masked by the higher accumulation rates of calcareous organisms. Within 30 to $40 \mathrm{~m} . \mathrm{y}$., the siliceous fossils dissolve, and silica ions migrate through the sediments and reprecipitate as opal-CT and quartz, which form porcellanite and chert beds or nodules. In addition to abundant carbonate sediments, chert and porcellanite also characterize a large part of the Cretaceous sections in the western Pacific. Volcanic ash and non-volcanic wind-transported materials are important sedimentary components, but are often masked by high rates of biogenic sedimentation. Volcanogenic sediment does form discrete beds when deposited by air fall after a large eruption, or when deposited from turbidity currents or debris flows (e.g., Line Islands apron; Schlanger, Jackson, et al., 1976). Wind-transported non-volcanogenic components generally do not form discrete beds in open-ocean deposits.

This paper describes volcanogenic components in sediments that were recovered during DSDP Leg 62 (Fig. 1) and relates the time and space relationships of those components to the geologic histories of the MidPacific Mountains and Hess Rise specifically, and to other rises in the western Pacific in general. We present

\footnotetext{
${ }^{1}$ Initial Reports of the Deep Sea Drilling Project, Volume 62.
}

data that indicate distinct pulses of activity and show that volcanism contributed a significant volume to the sediment piles, particularly in the Lower Cretaceous of Site 463 . Volcanic contributions to sediment in oceanic areas far from active island arcs are not well understood. We hope that through studies such as this some understanding of the genesis and volcanic histories of the early Pacific and its rises will be gained.

Volcanogenic components (as defined by Vallier and Kidd, 1977) of sediments include both primary and secondary materials that result from volcanic activity. Products are pyroclastic, epiclastic, and authigenic in origin and can consist of primary volcanic materials such as volcanic glass, feldspar, pyroxene, volcanic rock fragments, etc., and (or) secondary minerals such as montmorillonite, palagonite, zeolites, palygorskite, and silica minerals.

In this study we rely on analyses of stratigraphic relationships, smear-slide data, carbon-carbonate data, and X-ray diffractograms for identification of volcanogenic contributions to the sediment columns. Dominant volcanogenic components are secondary montmorillonite, a known diagenetic product of volcanic glass (e.g., Peterson and Griffin, 1964), and primary volcanic glass, feldspar, and opaque minerals. The minor contribution by zeolites, the absence of palygorskite, and the direct relationship between radiolarian dissolution and the secondary silica minerals opal-CT and quartz make the analyses in this report simpler and more straightforward than those of cores from the Indian Ocean, where somewhat arbitrary percentages were employed to quantify volcanic contributions (Vallier, 1974; Vallier and Kidd, 1977).

\section{METHODS}

Routine megascopic descriptions of cores aboard the Glomar Challenger were followed by sampling of those intervals where volcanogenic materials were suspected. Some volcanic materials are in discrete, clay-rich, black and dark-gray beds within intervals of white and light-gray carbonate sediments. Other samples were selected from 




Figure 1. Map showing all sites drilled on the Mid-Pacific Mountains and Hess Rise.

areas in the cores where color changes occur-such as from white or light gray to dark gray, and where preliminary smear-slide studies revealed the presence of volcanic glass or abundant clay minerals. At Site 464 , on northern Hess Rise, the brown clay and greenish-gray siliceous-fossil ooze in the Tertiary also were examined for volcanogenic components.

During shore-based investigations, samples were studied in more detail by smear-slide petrography, carbon-carbonate analyses, and $\mathrm{X}$-ray mineralogy. Smear-slide results are necessarily qualitative; percentages were estimated and subsequently grouped into categories: dominant, if a component made up more than $50 \%$ of the smear slide; abundant, 25 to $50 \%$; common, 5 to $25 \%$; and rare, present but less than $5 \%$.

A Leco WR-12 analyzer was used for carbon-carbonate determinations. Sample preparation and analyses followed established DSDP procedures (Boyce and Bode, 1972). Accuracy of the Leco was determined by using standards of known carbon content, and precision was $\pm 2 \%$. Total carbonate percentages are assumed to represent $\mathrm{CaCO}_{3}$.

Bulk X-ray analyses were made on a Norelco diffractometer. Samples were prepared by drying and then grinding to a fine powder. A thick paste made from the powder was spread evenly onto a glass slide; after drying in a desiccator, it was run from 3 to $60^{\circ} 2 \theta$ at a rate of $1 \% \mathrm{~min}$. Results from bulk analyses are qualitative. Percentages of sample constituents were determined by primary peak height and peak width and divided into the following fields: dominant, greater than $75 \%$; abundant, 25 to $75 \%$; common, 5 to $25 \%$; and rare, less than $5 \%$.

For studies of clay $(<2 \mu \mathrm{m})$ mineralogy, powdered samples were soaked in equal parts of $30 \%$ hydrogen peroxide and Morgan's solution to remove organic matter and calcium carbonate. The $<2 \mu \mathrm{m}$ size fraction was separated by centrifugation, $\mathrm{Mg}$-saturated with $\mathrm{IM}$ $\mathrm{MgCl}$, and washed with distilled water. Clays were smeared on a glass slide and run from 3 to $14^{\circ} 2 \theta$ at $1^{\circ} / \mathrm{min}$, and from 24 to $26^{\circ} 2 \theta$ at $1 / 4 \%$ min. Analyses of the diffractograms followed the methods of Biscaye (1965) and Hein et al. (1976). In this report, all minerals of the smectite family are referred to as montmorillonite.

\section{RESULTS}

Smear-slide, X-ray, and carbon-carbonate results are shown in Figures 2 and 3 . The more-detailed stratigraphic, paleontologic, and sedimentologic data given in the respective site reports (this volume) are reviewed in this section and in Figure 4. 


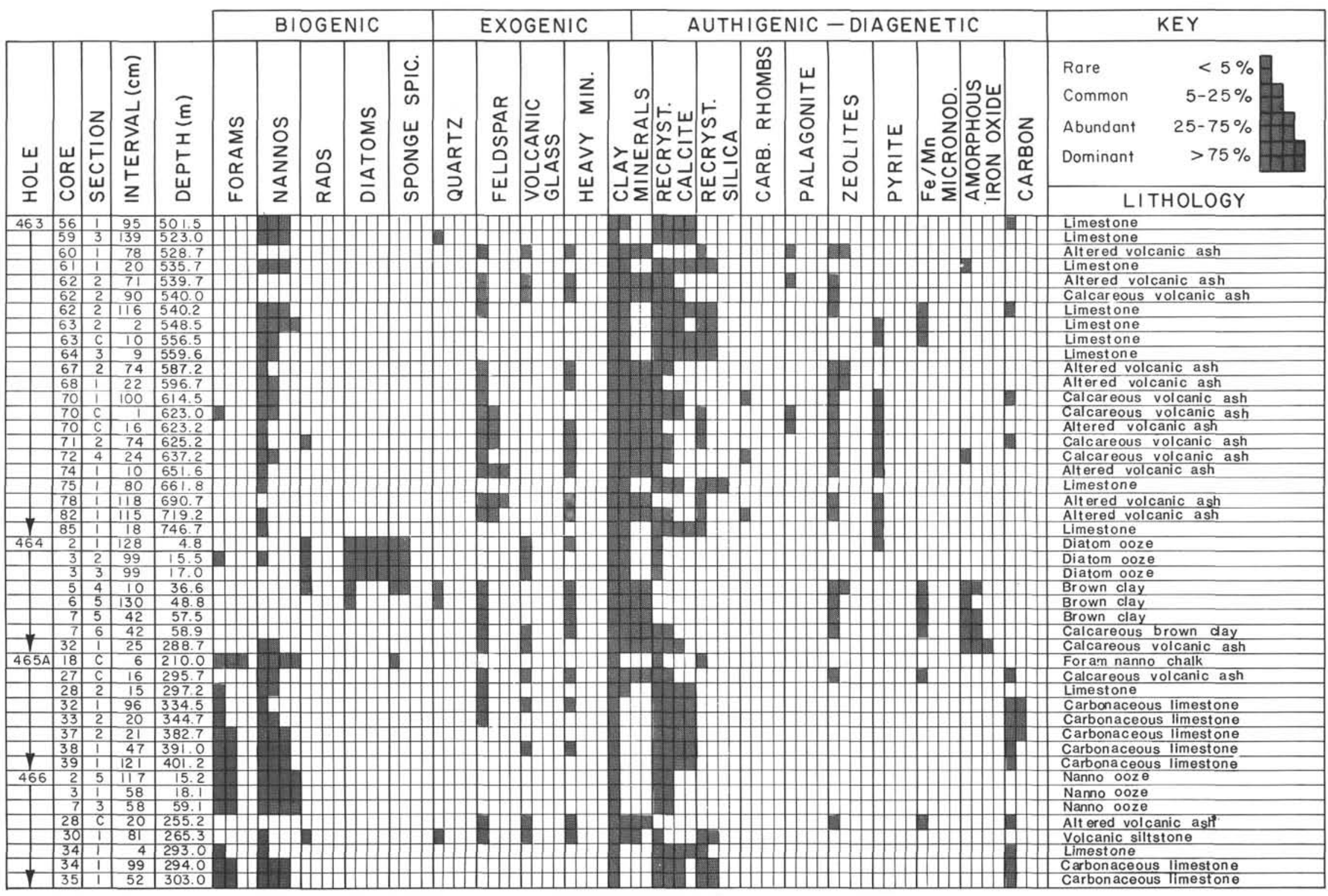

Figure 2. Results of smear-slide analyses of samples selected for this study. Most samples correspond to those in Figure 3. 




Figure 3. X-ray mineralogy and carbon-carbonate results. 


\section{Site 463, Mid-Pacific Mountains}

We continuously cored 823 meters of sediments and sedimentary rocks in the western part of the Mid-Pacific Mountains at Site 463, where the sediment column was divided into four major lithologic units (Fig. 4). Igneous crust was not penetrated. The oldest unit, at least 190 -meters thick, is interbedded pelagic and clastic limestone of Early Cretaceous (mostly Barremian) age. Shallow-water carbonate debris consisting of oolites, mollusk and stromatolite fragments, and rare glauconite grains were discovered in many of the clastic limestone beds. An overlying unit, 45-meters thick, is a carbonaceous limestone of Early Cretaceous (early Aptian) age with interbeds of altered volcanic ash (bentonite). Many samples from this unit have high organic-carbon contents (Thiede et al., 1979). The overlying unit, 136-meters thick, is Aptian through middle Albian multicolored limestone with common chert. The top unit is 452-meters thick and consists of 405 meters of upper Albian to lower Maastrichtian ooze, chalk, limestone, porcellanite, and chert, and 47 meters of Eocene through Pleistocene nannofossil ooze.

The sediment sequence is interrupted by two significant hiatuses; the oldest represents early Maastrichtian through early Eocene time, and the youngest represents late Oligocene through middle Miocene time. Two condensed parts of the sediment column that may contain lacunas occur in the upper Santonian through middle Campanian and in the middle Eocene through most of the Oligocene.

Rare silicic volcanic-glass shards that occur in the upper part (Neogene) of the cored sequence probably are related to air fall from eruptions of volcanoes that lie along western Pacific island arcs. Kennett et al., (1977) discussed the increased volcanism around the Pacific rim during the corresponding time.

Rea and Janecek (this volume) noted an increase in the non-authigenic, inorganic, crystalline, eolian component in the Campanian-lower Maastrichtian sediments from Hole 463 and attributed the increase to volcanic contributions. The probable volcanogenic components are age-correlative with volcanic sediments at Horizon Guyot and along the Line Islands (Winterer, Ewing, et al., 1973; Larson, Moberly, et al., 1975; Schlanger, Jackson, et al., 1976), which indicates that volcanism may have been widespread during this time in nearby areas. Rea and Thiede (in press) discuss a similar volcanic event in the western Pacific and conclude that many parts of the western Pacific (e.g., Caroline, Marshall, Gilbert, and Line Islands) contained volcanic islands during Campanian-early Maastrichtian time.

Most volcanogenic sediments in the sequence at Site 463 are between sub-bottom depths of 500 meters (lower Albian) and 750 meters (Barremian); highest percentages occur in the lower Aptian limestone sequence. The youngest volcanic components occur in Core 50, at a sub-bottom depth of about 450 meters, in upper Albian limestone and chalk beds where traces of volcanic glass and higher clay contents in the samples indicate some volcanic input. The youngest recognizable altered-ash bed is in upper Aptian sediments of Core 60. Abundant montmorillonite in a sample from Core 61 (Fig. 3) and a thick bentonite or altered-ash bed in Core 62 (Fig. 5) further indicate the influence of volcanism on sedimentation in the upper Aptian section. Lower Aptian and Barremian carbon- and clay-rich limestone occurs in Cores 64 through 79 and represents the strongest volcanic input in the sediment column. Figure 6 portrays the dark colors and lamination of sediments. Volcanism occurred as early as the Barremian, as shown by abundant montmorillonite and rare volcanic glass in samples from Cores 82 and 85 (Fig. 3).

The volcanic-ash beds of Lower Cretaceous cores at Site 463 are extensively altered. Authigenic montmorillonite is the dominant component, formed mostly from the breakdown of volcanic glass; feldspar, heavy minerals, zeolites, palagonite, and opaque minerals occur as rarer components.

The volcanic ash is mixed with calcium carbonate in various proportions. Color of the sediment is related both to the clay:carbonate ratio and to the organiccarbon content. The large amount of organic carbon in the lower Aptian sediments apparently influences sediment color. However, in the underlying Barremian limestone, dark-colored beds have high clay contents and low percentages of organic carbon, suggesting that clay content also affects colors. Throughout the Lower Cretaceous beds of Site 463, clay and organic-carbon contents (Fig. 7) are both related to (Field II of Fig. 7) and independent of (Fields I and III) each other. Therefore, it is apparent that volcanism (clay content) was not directly responsible for the accumulation of all organic carbon. Rather, other factors governed the accumulation and survival of the organic materials.

Igneous crust was not penetrated at Site 463 , and we know neither its sub-bottom depth nor composition. However, the coarseness of debris and the occurrence of shallow-water fossils in the oldest recovered sediments suggest that a carbonate platform was near Site 463 during the Barremian and early Aptian. The carbonate platform likely formed around a volcanic island (or islands) similar to the platforms and reefs that border many of the present-day islands in the western Pacific. Therefore, a volcanic pedestal probably underlies the oldest unit, and we presume the age (Barremian) of the oldest sediment drilled is close to the age of igneous crust. Volcanic rocks from other parts of the Mid-Pacific Mountains are alkali basalt from Horizon Guyot (Bass et al., 1973) and alkali olivine basalt from dredge hauls recovered both east and west of Site 463 (Natland, 1976). These results suggest that explosive alkalic volcanism and the erosion of debris from volcanic islands were the sources of volcanic components in the Lower Cretaceous sediments of Site 463 .

\section{Site 464, Northern Hess Rise}

At Site 464 we cored continuously and encountered altered tholeiitic basalt at a sub-bottom depth of 308 meters. The overlying sediments range in age from early Albian to Pleistocene and are divided into three units (Fig. 4). Lower Albian to Cenomanian chalk, marl- 

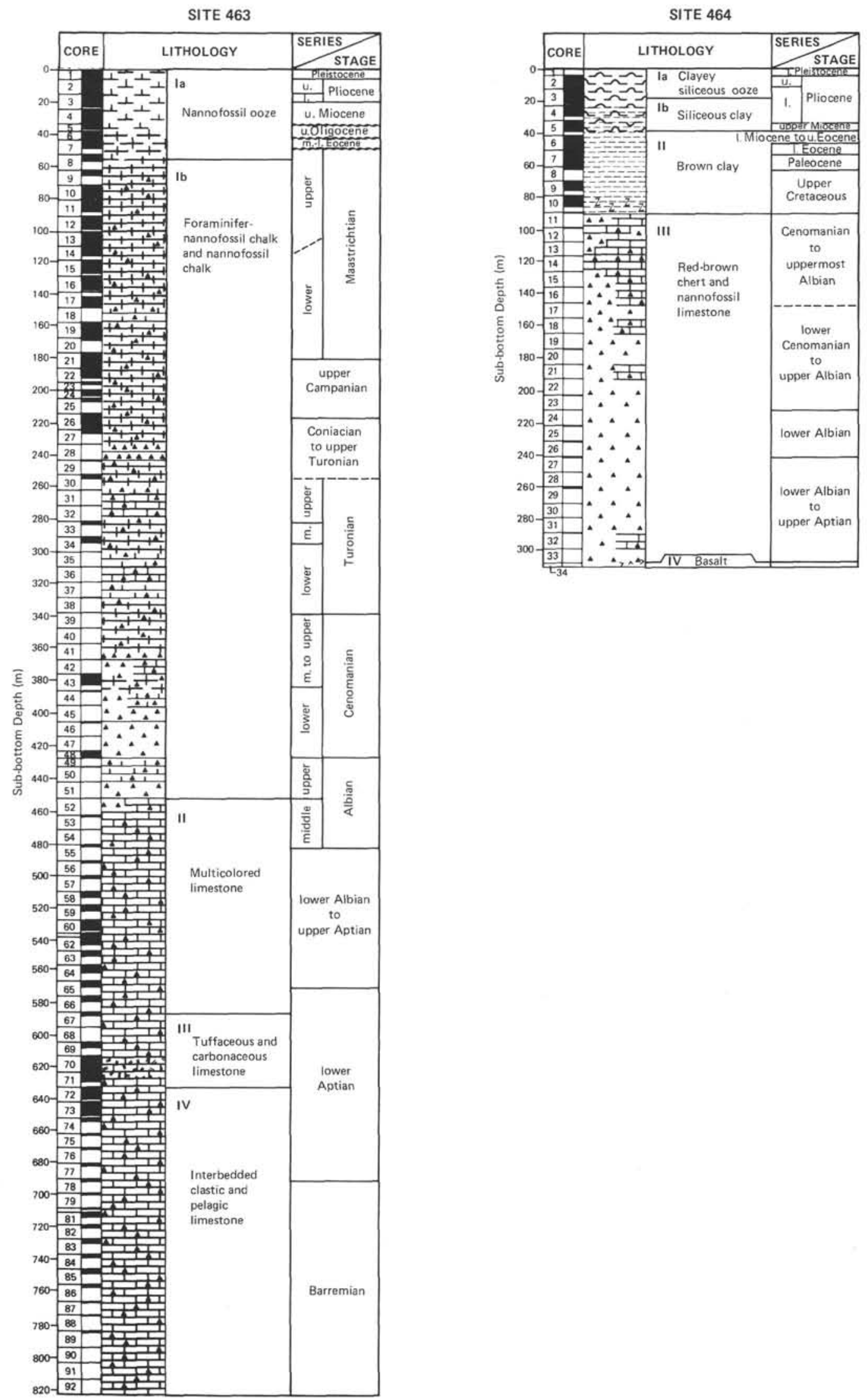

Figure 4. Stratigraphic columns of holes drilled during Leg 62. Ages and lithologies are based mostly on shipboard studies. 


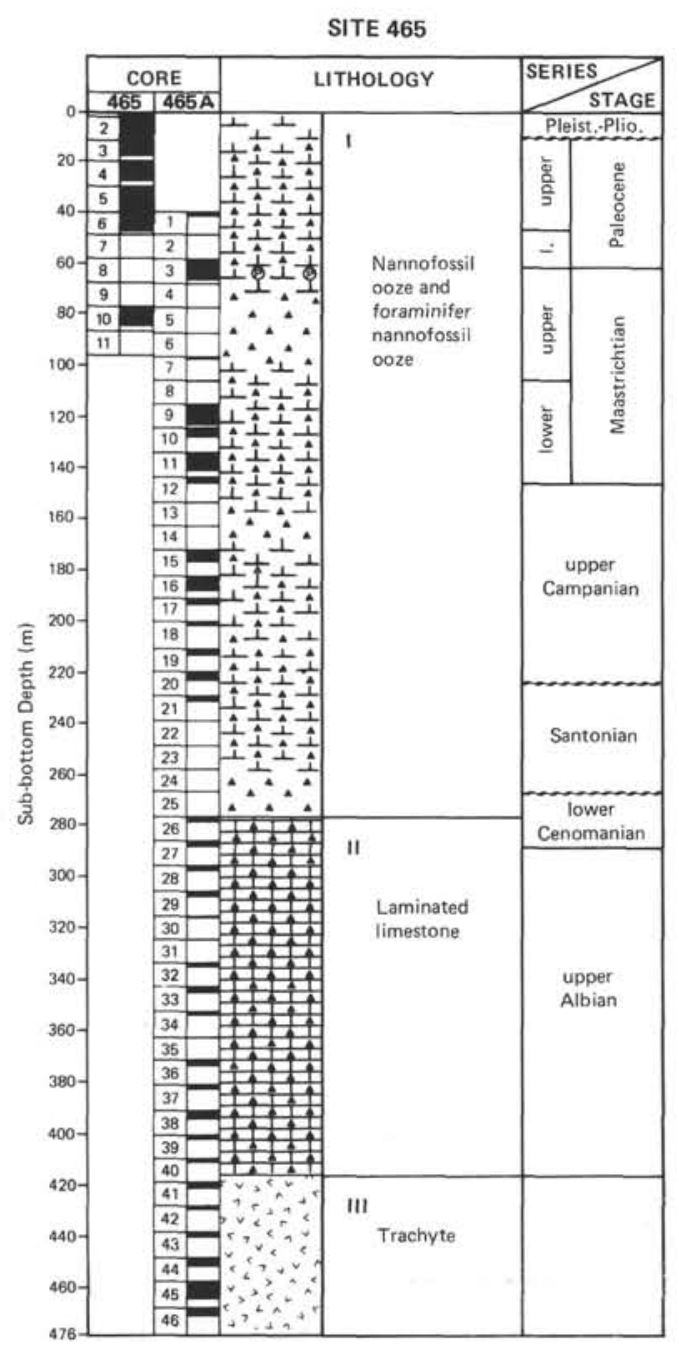

Figure 4. (Continued).

stone, porcellanite, and chert make up the lowest unit, which is 219-meters thick. Very poor recovery, caused by chert and porcellanite (Fig. 8), make interpretations tenuous, because most soft sediments were washed away during the coring process.

The middle unit consists of 53 meters of pelagic brown clay which, according to a study of ichthyoliths (Doyle and Riedel, this volume), ranges in age from Late Cretaceous to middle Miocene. The youngest unit is 36-meters thick and consists of upper Miocene to Pleistocene green siliceous-fossil ooze and siliceousfossil clay.

No distinct ash beds were recognized in any of the units, and the amounts of volcanogenic components are estimated from the abundance of volcanic glass and montmorillonite. Estimated silicic volcanic glass constitutes a trace to $20 \%$ of smear slide components in the sequence of siliceous-fossil ooze and clay (youngest unit), and it constitutes trace amounts to $2 \%$ or more of smear-slide components in the underlying pelagic brown clay of the middle unit. A small bleb in this brown clay (Core 9, Section 1, $75 \mathrm{~cm}$ ) yielded more than $80 \%$



altered glass. Montmorillonite constitutes most of the $<2-\mu \mathrm{m}$ fraction in samples from the brown clay unit (Fig. 3). Traces of volcanic glass (up to $5 \%$ of the insoluble residue) and a high montmorillonite content in the $<2-\mu$ m clay fraction from 464-32-1, $25 \mathrm{~cm}$ (Fig. 3) indicate volcanic contributions in the lower Albian sediment of the oldest unit. Dark colors of the albian sediments reflect both high organic-carbon and clay contents.

It is likely that the silicic volcanic glass, at least in the upper unit at Site 464 , is related to wind transport of materials from explosive volcanism on island arcs of the western Pacific. The glass and montmorillonite contents in the brown clay (middle unit) might be related to eruptions not only from volcanoes on island arcs of the western Pacific, but also from volcanoes of the Emperor Seamounts, some of which probably were above sea level during the early Tertiary. Volcanic contributions in the lower Albian-Cenomanian sequence (oldest unit) likely are associated with volcanism that was related to the early formation of sea floor (and oceanic islands) in the region. 


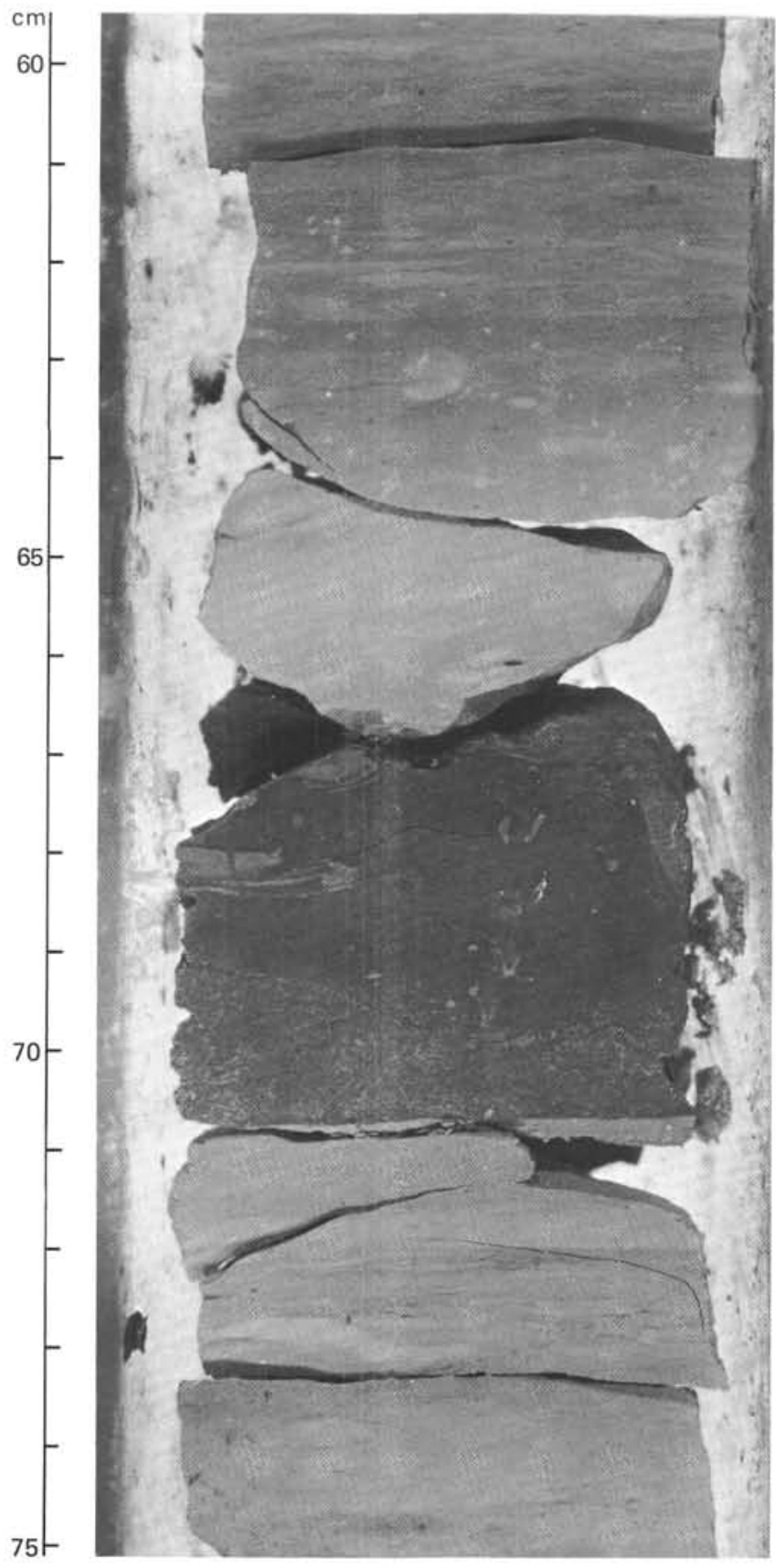

Figure 5. Photograph of core interval 463-62-2, 60-75 cm, showing a burrowed, altered volcanic ash (bentonite).

\section{Site 310, Central Hess Rise}

Cores from Site 310 (Holes 310 and 310A), on central Hess Rise (Larson, Moberly, et al., 1975) contain only very small amounts of volcanic components. Core recovery was exceptionally poor because of abundant chert in the cored sections. A small fragment of pink volcanic claystone in the core catcher sample of Core 20 , Hole 310 , is early Campanian. In the core catcher of Core 17 , Hole $310 \mathrm{~A}$, a sample of zeolitic pelagic clay of late Albian-early Cenomanian age contains volcanic glass. Such fragmentary evidence, however, suggests

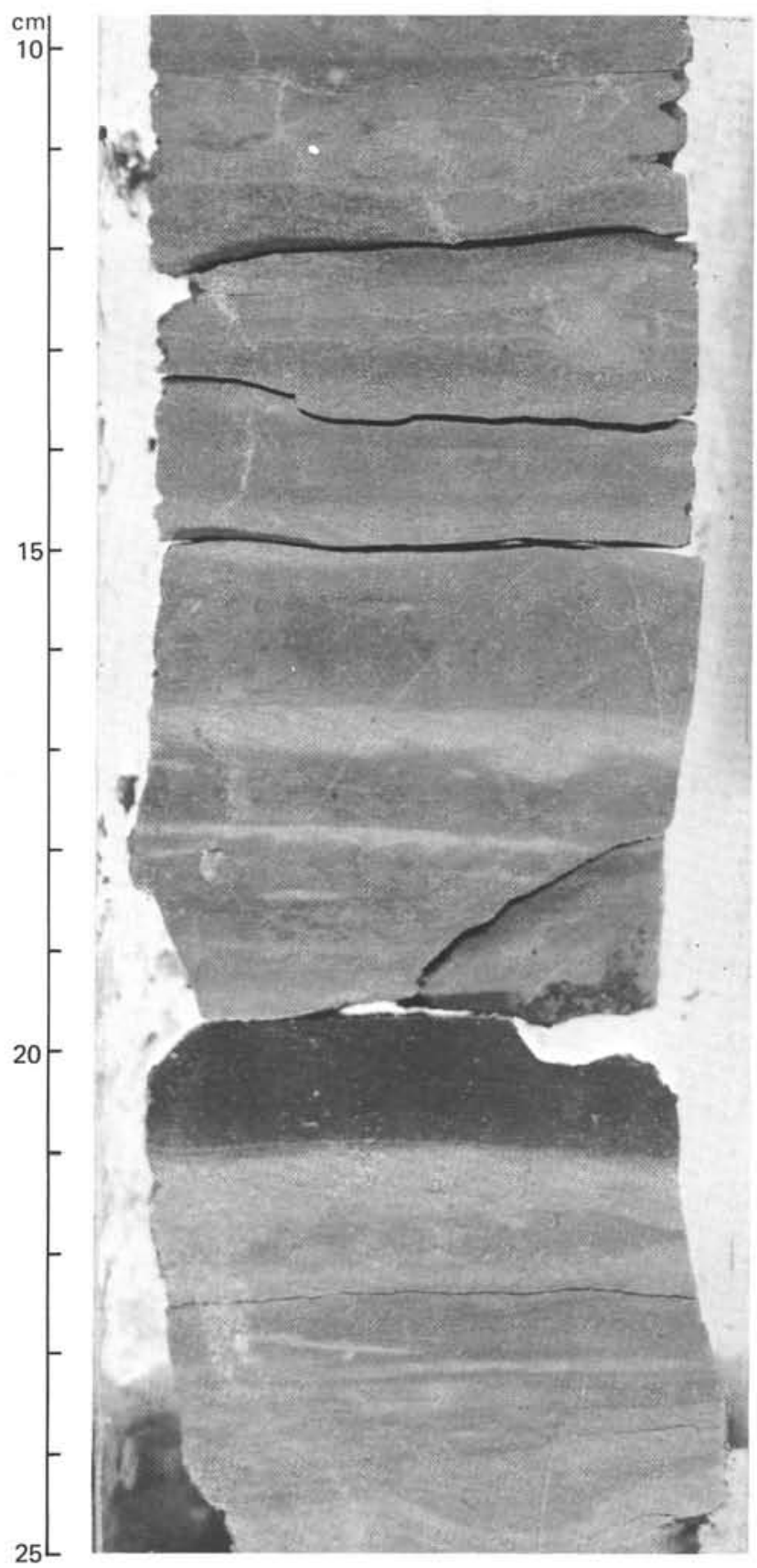

Figure 6. Photograph of core interval 463-70, CC, 10-25 cm, showing typical sediment of the lower Aptian carbonates. A sample from 16 to $18 \mathrm{~cm}$ contains only montmorillonite in the $<2 \mu \mathrm{m}$ fraction and has $19 \% \mathrm{CaCO}_{3}$ and $0.7 \%$ organic carbon (Figs. 2 and 3 ).

that some volcanogenic components occur in both Lower and Upper Cretaceous sediment, but problems with original stratigraphic positions and ages of the core-catcher samples make further interpretations equivocal.

\section{Site 465, Southern Hess Rise}

At Site 465 (Holes 465 and $465 \mathrm{~A}$ ) we continuously cored to a sub-bottom depth of 476 meters and divided the column into two sediment units that overlie a basal 


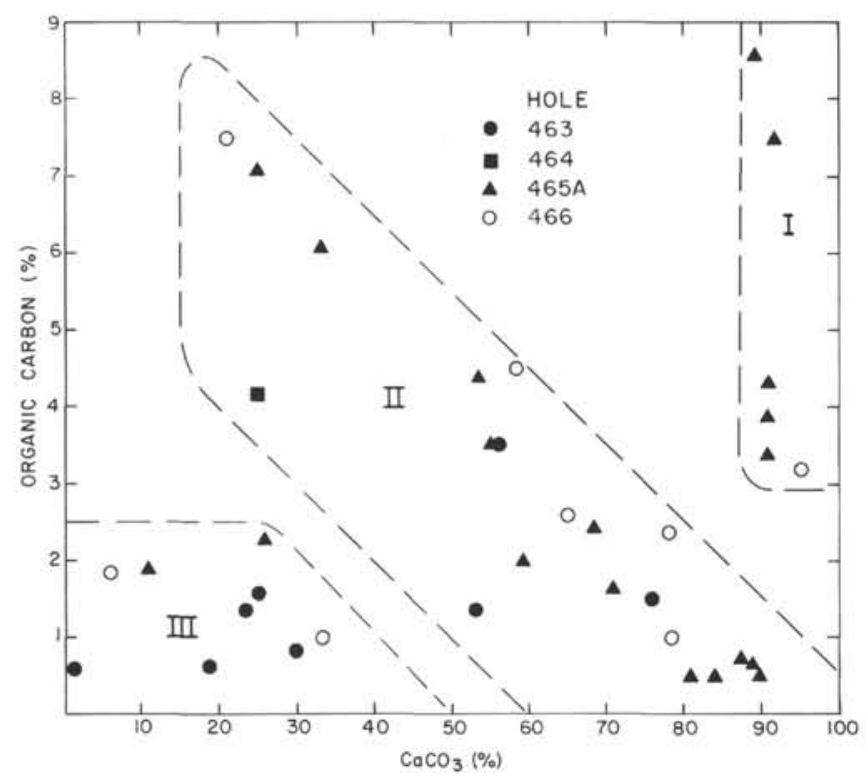

Figure 7. $\mathrm{CaCO}_{3}$ plotted against organic carbon for samples with more than $0.5 \%$ organic carbon. $\mathrm{CaCO}_{3}$ content increases to the right, and other components, specifically clay (altered volcanic ash) and silica minerals, increase to the left. Field I contains plots of samples that are almost entirely composed of $\mathrm{CaCO}_{3}$ and organic carbon. There is no relationship between organic carbon and non- $\mathrm{CaCO}_{3}$ components such as clay. Field II shows a relationship between organic carbon and non- $\mathrm{CaCO}_{3}$ (mostly clay) contents. Field III shows an abundance of non- $\mathrm{CaCO}_{3} \mathrm{com}$ ponents, mostly silica minerals and rarely clay, in sediments with high organic-carbon contents.

volcanic-flow unit (Fig. 4). The volcanic flow rocks are trachyte (Seifert et al., this volume) with large vesicles (5 $\mathrm{mm}$ to $2 \mathrm{~cm}$ ) and rare oxidized flow boundaries, which suggest subaerial or shallow submarine eruptions. Overlying the trachyte flows is an upper Albian-lower Cenomanian laminated-limestone unit 136-meters thick. The top unit, consisting of Coniacian through Pleistocene nannofossil ooze, foraminifer-nannofossil ooze, chalk, and chert, is continuous from the sea floor to 276 meters (Core 25 of Hole 465A). Hiatuses represent early Cenomanian to late Coniacian, late Santonian to late Campanian, and late Paleocene to early Pliocene times which comprise about $75 \%$ of the time since the late Albian.

Smear-slide analyses carried out aboard the ship during Leg 62 indicate that volcanic glass constitutes a trace to $3 \%$ in the Paleocene samples (Fig. 2). In Maastrichtian sediments of Core 11 , Hole 465 , volcanic glass constitutes approximately $60 \%$ in a smear slide from the core-catcher sample, and from a trace to $20 \%$ in samples of late Maastrichtian-early Paleocene age in Core 3 of Hole 465A. Volcanic glass also occurs in lower Maastrichtian cores and in lower Cenomanian-upper Albian samples from Hole 465A. Mineralogies of the $<2-\mu \mathrm{m}$ clay fractions from both upper Campanian and lower Cenomanian sediments are $100 \%$ montmorillonite (Fig. 3 ), which indicates a significant influx of fine-grained volcanic materials.

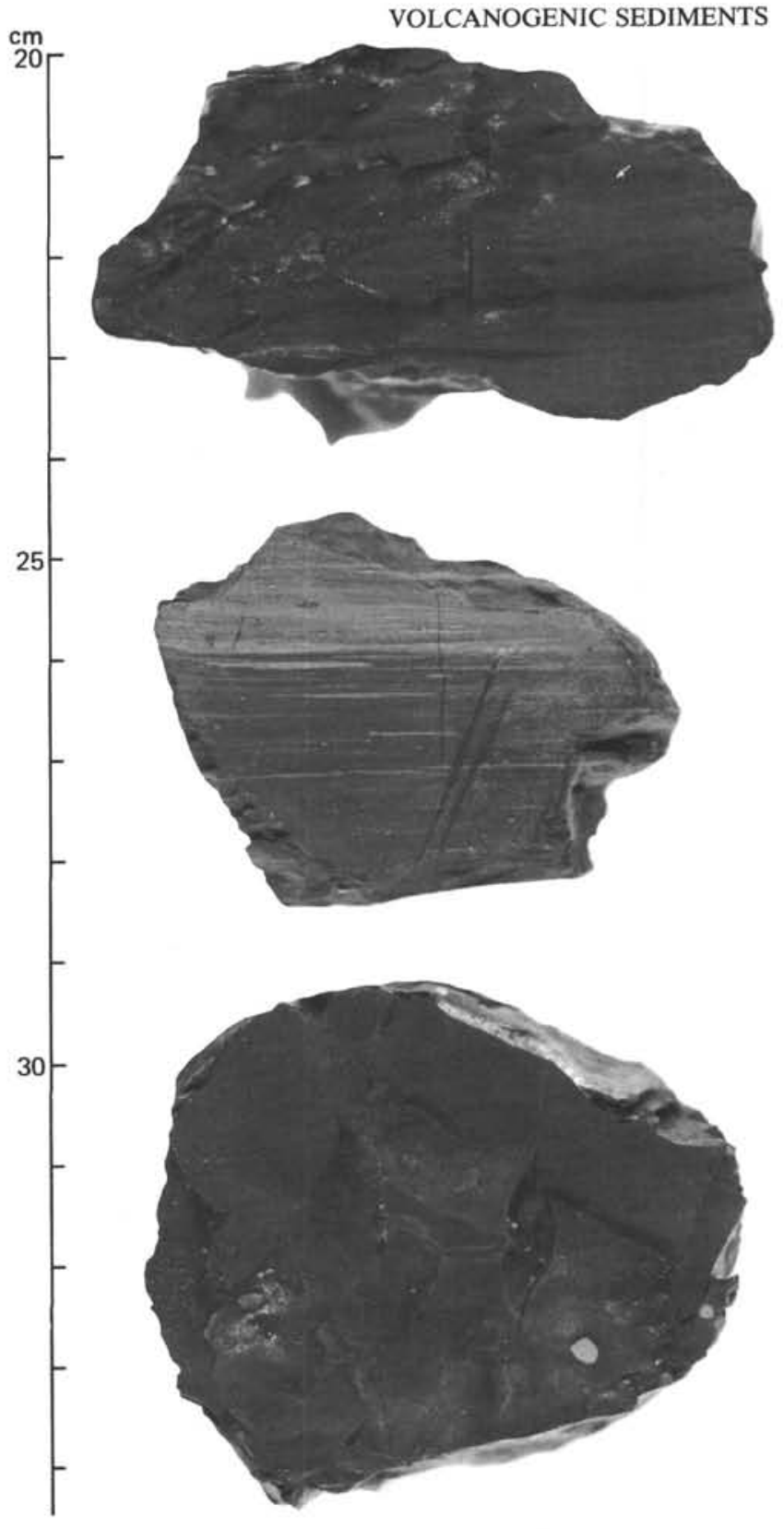

Figure 8. Chert fragments in core interval 464-32-1, 20-35 cm, showing the nature of recovery from a large part of Hole 464 . All soft sediments were washed away during the coring process.

Distinct ash beds are absent in cores from Site 465 . However, volcanic glass and the prevalence of montmorillonite in the Cretaceous and Paleocene samples indicate that volcanic activity did occur. The dark color of limestone in Core 27 of Hole 465A (Fig. 9) is due to high organic-carbon and clay content, whereas in older sediments the dark color is more closely correlated with organic-carbon content (Figs. 3 and 7).

We conclude that volcanism occurred during both the late Albian to early Cenomanian and Maastrichtian to Paleocene; however, we do not know the source area or the original composition of the volcanic components. 


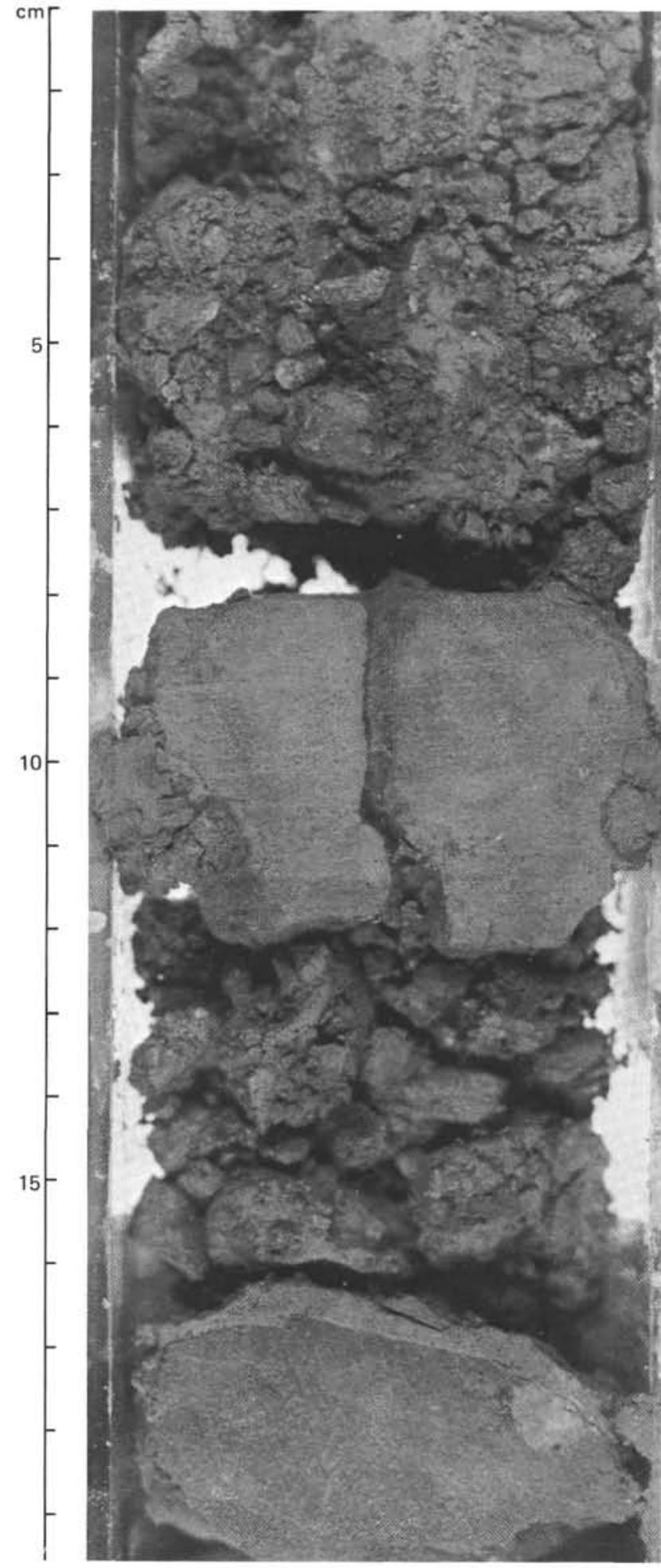

Figure 9. Dark colored calcareous ash and limestone in Hole 465 A-27, CC. Organic carbon content at $16 \mathrm{~cm}$ is $2.3 \%$ and $\mathrm{CaCO}_{3}$ is $25.8 \%$. All clay ( $<2 \mu \mathrm{m}$ fraction) is montmorillonite.

Alkalic basalt clasts in Upper Cretaceous cores from nearby Hole 466 suggest that oceanic islands were being eroded during that time (Vallier et al., this volume). The source volcanoes probably were close, along what is now the very irregular east-west crestal region of southern Hess Rise.

\section{Site 466, Southern Hess Rise}

At Site 466 we cored 312 meters before terminating the hole. Low recovery was caused by the prevalence of chert in the Cretaceous sequence. The hole bottomed in a lithologic unit of upper Albian chalk and limestone, equivalent to the lower limestone unit in Hole 465A. The sediment column at Site 466 is divided into two units; the upper unit consists of Cenomanian(?) to Pleistocene nannofossil ooze and chert-rich nannofossil ooze and chalk, to a sub-bottom depth of 246 meters, and a lower unit of upper Albian olive-gray nannofossil chalk and limestone cored between sub-bottom depths of 246 and 312 meters (Fig. 4). Igneous rocks were not penetrated.

Three major hiatuses occur within the cored sequence: (1) late Santonian through part of the late Campanian; (2) early Maastrichtian through early Eocene; and (3) Oligocene through early Pliocene. A relatively thin Cenomanian through Coniacian section may also be interrupted by a hiatus.

We estimate that as much as $5 \%$ volcanic glass occurs in smear slides from Pliocene and Pleistocene cores, and as much as 2\% in Eocene cores of the upper unit. Volcanic glass is rare in the Cretaceous cores of the lower unit. Strong evidence for the erosion of volcanic land masses is found in Upper Cretaceous cores (Vallier et al., this volume). The clasts may have been deposited along the lower Maastrichtian-middle Eocene unconformity and caved into the hole during the drilling process. These clasts, whether deposited in the Late Cretaceous or earliest Tertiary, indicate that volcanic islands were being eroded and suggest that some volcanic activity may have occurred during the Late Cretaceous to middle Eocene. An alternative hypothesis is that the clasts were eroded from tectonically uplifted older crust, with no contemporaneous volcanism.

High montmorillonite contents and some glass in samples from the oldest unit (Figs. 10 and 11) indicate that volcanism contributed significant volumes of material to the sediment pile during the late Albian to early Cenomanian; the volcanism probably was related to the early evolution of Hess Rise.

\section{DISCUSSION AND CONCLUSIONS}

Our major conclusions with regard to the timing of Leg 62 volcanogenic-sediment deposition are given in Figure 12. Significant deposition of volcanic ash occurred at Site 463 on the Mid-Pacific Mountains during the Barremian to early Aptian, and Albian to early Cenomanian volcanism contributed abundant sediments to Hess Rise. Apparently, these volcanic eruptions are related to early stages of formation of these rises.

A Late Cretaceous volcanic event during the Campanian to Maastrichtian (possibly Paleocene) occurred on Hess Rise, as shown by high montmorillonite contents in the carbonates from Holes 465 and 466 , and by ash in a core-catcher sample from Site 310 . The basaltic 


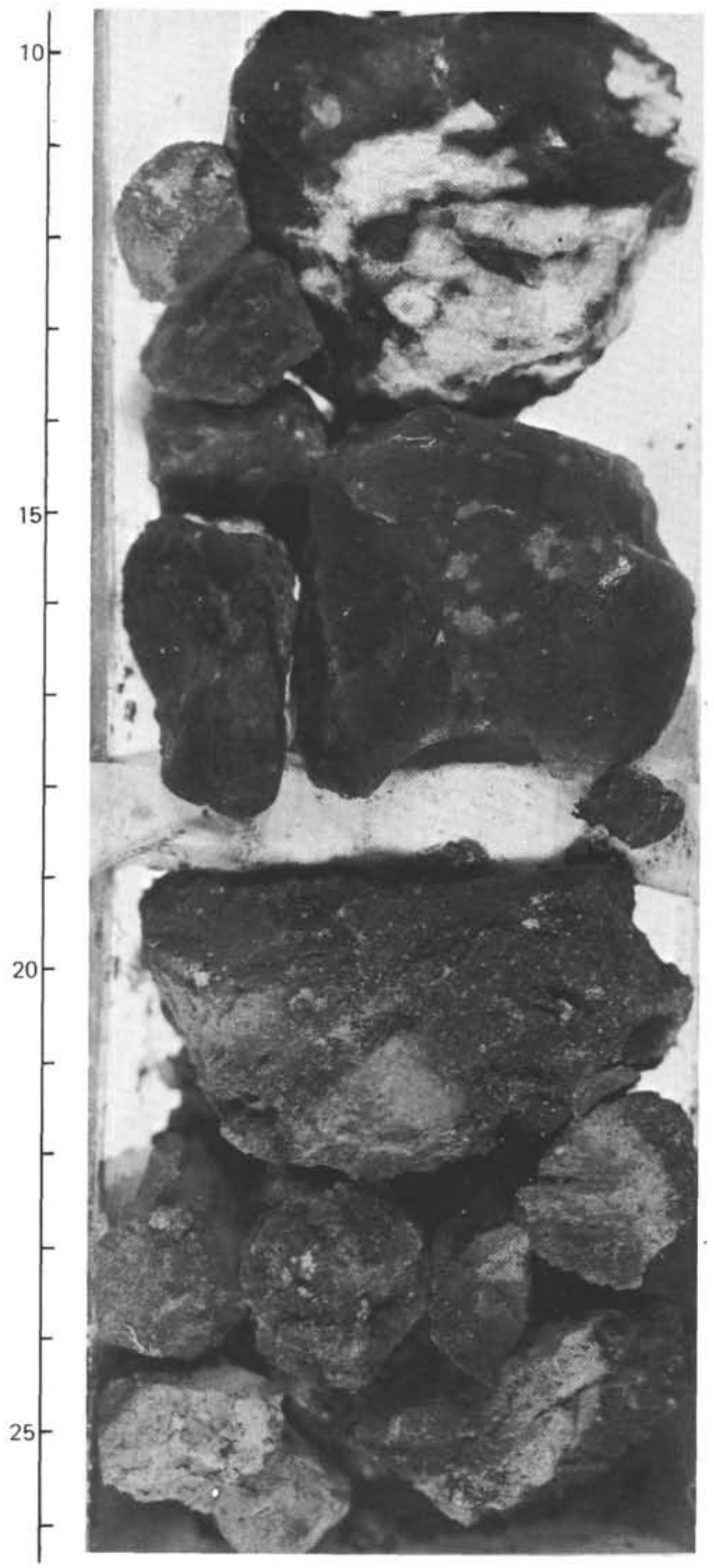

Figure 10. Altered volcanic ash in core interval $466-28, C C, 20 \mathrm{~cm}$, with $100 \%$ montmorillonite in the $<2-\mu \mathrm{m}$ clay fraction. Chert (upper part of the photograph) is ubiquitous.

clasts in cores from Site $\mathbf{4 6 6}$ may signify either erosion of an older uplifted volcanic terrain or volcanism during the Late Cretaceous to earliest Tertiary. There also is some evidence for volcanism during this time in sediments from Site 463, as shown by Rea and Janecek (this volume). Volcanic components in the brown-clay unit

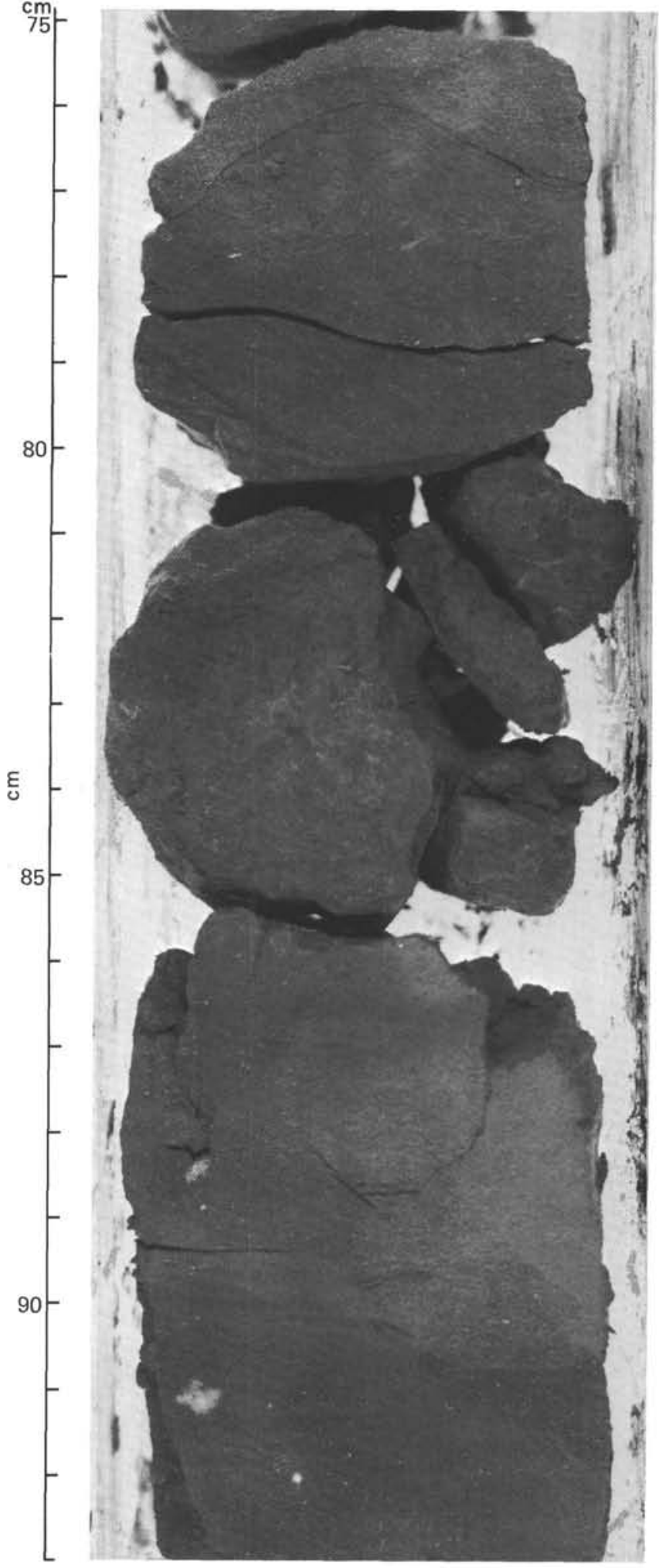

Figure 11. Photograph of core interval 466-30-1, 75-93 cm, showing limestone with high percentages of recrystallized radiolarians, montmorillonite, and organic carbon. A sample from $81 \mathrm{~cm}$ corresponds to the circle at the far left in Figure 7. 


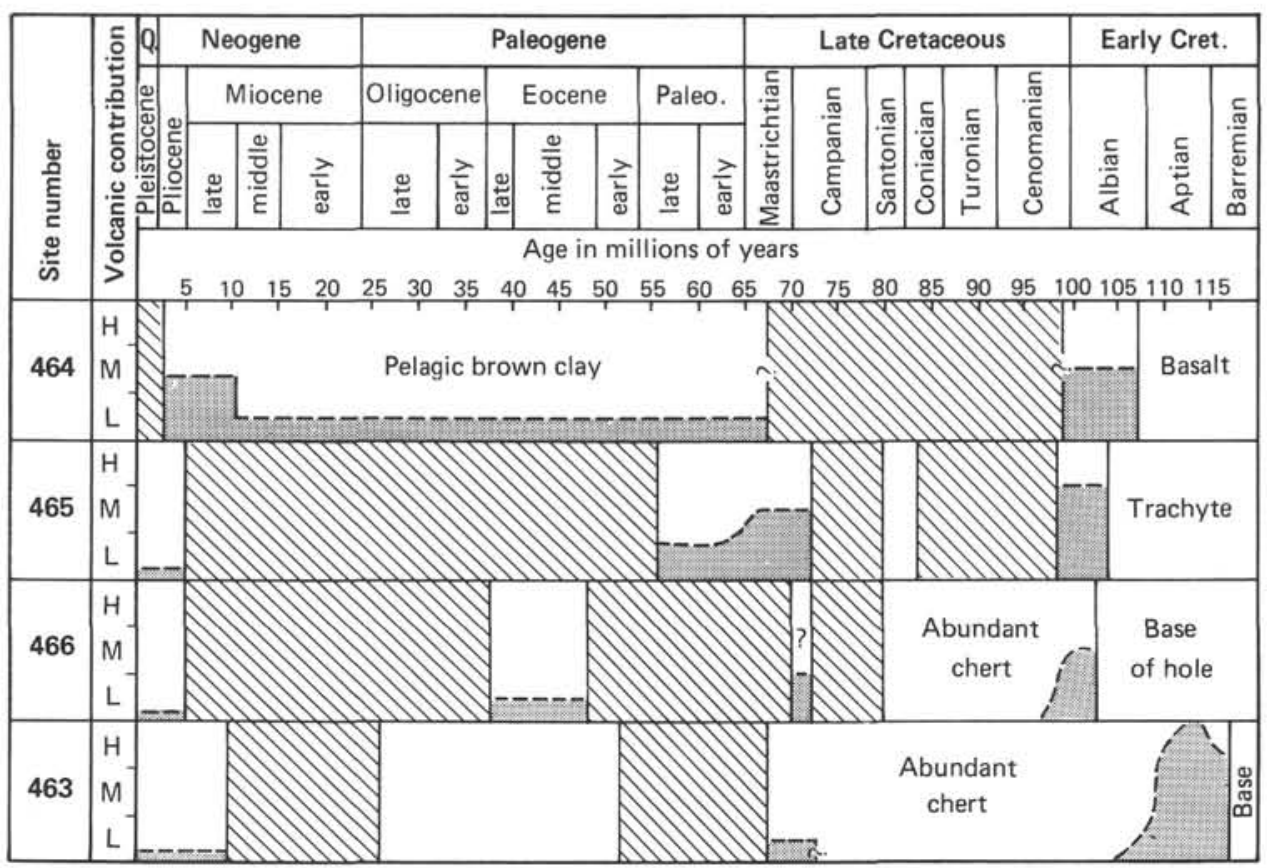

Figure 12. Volcanogenic contributions to sediments at Sites $463,464,465$, and $466 . \mathrm{L}=$ low contributions, $<5 \%$ volcanic glass; $M=$ medium contributions, $>5 \%$ glass and abundant montmorillonite in the $\langle 2-\mu \mathrm{m}$ fraction; and $\mathrm{H}=$ high contributions, ash beds and high montmorillonite content in the $<2-\mu \mathrm{m}$ fraction. The time scale is from Berggren (1972) and van Hinte (1976). Ruled areas represent hiatuses.

of Hole 464 suggest that some volcanism was occurring on island arcs along the Pacific rim and (or) on Emperor Seamounts (islands) during the latest Cretaceous to Pliocene; glass in the Plio-Pleistocene unit probably is related to eruptions of stratovolcanoes on island arcs of the western Pacific.

Cretaceous volcanogenic sediments recovered from holes drilled during Leg 62 can be correlated with volcanogenic sediments from DSDP holes drilled elsewhere in the western and central Pacific Ocean. Studies of the drilling results show that pulses of volcanic activity can be identified in the Barremian-Aptian, late Albianearly Cenomanian, and Santonian-Maastrichtian time intervals.

A major pulse of Cretaceous volcanism in the Barremian-Aptian interval occurred in the western Pacific. This Early Cretaceous volcanic activity is recorded in sediments of the deep northwestern Pacific basin at Site 307 (Larsen, Moberly, et al., 1975), and possibly at Site 194 (Heezen, MacGregor, et al., 1973). The event is well documented in sediments recovered at several sites on oceanic plateaus and rises-for example, on the MidPacific Mountains at Site 463 (site report, this volume), on the Ontong-Java Plateau at Sites 288 and 289 (Andrews, Packham, et al., 1975), and on the Manihiki Plateau at Site 317 (Schlanger, Jackson, et al., 1976). Plate-tectonic reconstructions by Lancelot (1978) showed that these sites were widely separated during Barremian to Aptian time. Winterer et al. (1974) showed that the Ontong-Java and Manihiki Plateaus actually may have formed along different segments of the same mid-ocean ridge during that time. This Early Cretaceous volcanism probably was related to the formation of rises and plateaus along a mid-ocean-ridge system, rather than to intraplate volcanism.

Another major volcanic event occurred during the late Albian to early Cenomanian on Hess Rise, and on Magellan Plateau at Site 167 (Winterer, Ewing, et al., 1973). The distance between Magellan and Hess Rises was not great about 100 m.y. ago (Lancelot, 1978), and it is possible that the volcanism was related both in time and space. However, Hess Rise apparently is younger than Magellan Rise, which suggests that Hess Rise volcanism might be related to its formation along or near a spreading center, whereas Albian-Cenomanian volcanism of Magellan Rise may be related to intraplate tectonism.

A significant volcanic event (or events) occurred during the Late Cretaceous in the western Pacific Ocean. Particularly important is a Santonian-Maastrichtian event, as shown by volcanogenic sediments in the eastern Mid-Pacific Mountains at Horizon Guyot and along the Line Islands chain (Winterer, Ewing, et al. 1973; Larsen, Moberly, et al. 1975; Schlanger, Jackson et al. 1976). An overlapping, but possibly distinct younger event occurred on Hess and Shatsky Rises (Larson, Moberly, et al., 1975).

Volcanic glass, mostly silicic, in upper Cenozoic cores at all sites probably is related to aerial transport of ash from volcanoes that line the island arcs of the western Pacific.

\section{ACKNOWLEDGMENTS}

We are particularly grateful to Hugh McLean and Steve Eittreim, who provided many helpful suggestions for the improvement of this paper. Jim Hein kindly allowed us the use of the X-ray laboratory. We 
thank Phyllis Swenson for assistance in preparing illustrations. We appreciate the scientific staff at DSDP, particularly Chuck Adelseck and Jerry Bode, for coordinating our use of the Leco equipment, and for assistance in providing core photographs.

\section{REFERENCES}

Andrews, J. E., Packham, G., et al., 1975. Init. Repts. DSDP, 30: Washington (U.S. Govt. Printing Office).

Bass, M. N., Moberly, R., Rhodes, J. M., et al., 1973. Volcanic rocks cored in the central Pacific, Leg 17, Deep Sea Drilling Project. In Winterer, E. L., Ewing, J. 1., et al., Init. Repts. DSDP, 17: Washington (U.S. Govt. Printing Office), 429-503.

Berggren, W. A., 1972. A Cenozoic time scale: some implications for regional geology and paleobiogeography. Lethaia, 5:195-215.

Biscaye, P. E., 1965. Mineralogy and sedimentation of recent deep sea clay in the Atlantic Ocean and adjacent seas and oceans. Geol. Soc. Am. Bull., 76:803-831.

Boyce, R. E., and Bode, G. W., 1972. Carbon and carbonate analyses, Leg 9, Deep Sea Drilling Project. In Hayes, J. D., et al., Init. Repts. DSDP, 9: Washington (U.S. Govt. Printing Office), 747-758.

Heezen, B. C., MacGregor, I. D., et al., 1973. Init. Repts. DSDP, 20: Washington (U.S. Govt. Printing Office).

Hein, J. R., Scholl, D. W., and Gutmacher, C. E., 1976. Neogene clay minerals of the far NW pacific and southern Bering Sea: sedimentation and diagenesis. In Bailey, S. W. (Ed.), AIPEA Proceedings, 1975 International Clay Conference, Mexico City, (Vol. 71), 71-80.

Jackson, E. D., and Schlanger, S. O., 1975. Regional syntheses, Line Islands chain, Tuamotu Island chain, and Manahiki Plateau, Central Pacific Ocean: In Schlanger, S. O., Jackson, E. D., et al., Init. Repts. DSDP, 33: Washington (U.S. Govt. Printing Office), 915-927.

Kennett, J. P., McBirney, A. R., and Thunell,R. C., 1977. Episodes of Cenozoic volcanism in the circum-Pacific region. J. Volcanol. Geothermal Res., 2:145-163.
Lancelot, 1978. Relations entre evolution sedimentaire et tectonique de la plaque Pacifique depuis le Cretace Inferieur. Mem. Soc. Geol. France, 134.

Larson, R. L., Moberly, R., et al. 1975. Init. Repts. DSDP, 32: Washington (U.S. Govt. Printing Office).

Natland, J. H., 1976. Petrology of volcanic rocks dredged from seamounts in the Line Islands. In Schlanger, S. O., Jackson, E. D., et al., Init. Repts. DSDP, 33: Washington (U.S. Govt. Printing Office), 748-777.

Peterson, M. N. A., and Griffin, J. J., 1964, Volcanism and clay minerals in the southeastern Pacific. J. Mar. Res., 22:287-312.

Rea, D. K., and Thiede, J., in press. Mesozoic and Cenozoic mass accumulation rates of the major sediment components in the Nauru Basin, western equatorial Pacific. In Larson, R. L., Schlanger, S. O., et al., Init. Repts. DSDP, 61: Washington (U.S. Govt. Printing Office).

Schlanger, S. O., Jackson, E. D., et al., 1976. Init. Repts. DSDP, 33: Washington (U.S. Govt. Printing Office).

Thiede, J., Vallier, T. L., Vincent, E., et al., 1979. Mid-Cretaceous oxygen-deficient paleoenvironments in the Mid-Pacific Mountains and on Hess Rise, central North Pacific. Abs. Prog. Am. Assoc. Petrol. Geol. Ann. Mtg., Houston, 174-175.

Vallier, T. L., 1974. Volcanogenic sediments and their relations to landmass volcanism and sea floor-continent movements, western Indian Ocean, Leg 25, Deep Sea Drilling Project. In Simpson, E. S. W., Schlich, R., et al., Init. Repts. DSDP, 25: Washington (U.S. Govt. Printing Office), 515-542.

Vallier, T. L., and Kidd, R. B., 1977. Volcanogenic sediments in the Indian Ocean. In Heirtzler, J. R. (Ed.), Indian Ocean Geology and Biostratigraphy: Washington (Am. Geophys. Union), pp. 87-118.

van Hinte, J. E., 1976. A Cretaceous time scale. Bull. Am. Assoc. Petrol. Geol., 60:498-516.

Winterer, E. L., Ewing, J. I., et al., 1973. Init. Repts. DSDP, 17: Washington (U.S. Govt. Printing Office).

Winterer, E. L., Lonsdale, P. F., Matthews, J. L., et al. 1974. Structure and acoustic stratigraphy of the Manahiki Plateau. Deep Sea Res., 21:793-814. 